Radiological Dose Assessment for the Decontaminated Concrete Removed from 183-H Solar Evaporation Basins at the Hanford Site, Richland, Washington.

Environmental Assessment Division Argonne National Laboratory

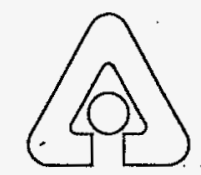

Operated by The University of Chicago,

under Contract $W-31-109-$ Eng-38, for the

United States Department of Energy 


\section{Argonne National Laboratory}

Argonne National Laboratory, with facilities in the states of Illinols and Idaho, is owned by the United States Government, and operated by the University of Chicago under the provisions of a contract with the Department of Energy.

This technical memo is a product of Argonne's Environmental Assessment Division (EAD). For information on the division's scientific and engineering activities, contact:

Director, Environmental Assessment Division

Argonne National Laboratory

Argonne, Illinois 60439-4815

Telephone (630) 252-3107

Presented in this technical memo are preliminary results of ongoing work or work that is more limited in scope and depth than that described in formal reports issued by the EAD.

Publishing support services were provided by Argonne's Information and Publishing Division (for more information, see IPD's home page: http://www.ipd.anl.gov/)

\section{Disclaimer}

This report was prepared as an account of work sponsored by an agency of the United States Government. Neither the United States Government nor any agency thereof, nor any of their employees, makes any warranty, express or implied, or assumes any legal liability or responsibility for the accuracy, completeness, or usefulness of any information, apparatus, product, or process disclosed, or represents that its use would not infringe privately owned rights. Reference herein to any specific commercial product, process, or service by trade name, trademark, manufacturer, or otherwise, does not necessarily constitute or imply its endorsement, recommendation, or favoring by the United States Government or any . agency thereof. The views and opinions of authors expressed herein do not necessarily state or reflect those of the United States Government or any agency thereof. 


\section{Radiological Dose Assessment for the Decontaminated Concrete Removed from 183-H Solar Evaporation Basins at the Hanford Site, Richland, Washington}

by S. Kamboj, E. Faillace, and C. Yu

Environmental Assessment Division,

Argonne National Laboratory, 9700 South Cass Avenue, Argonne, Illinois 60439

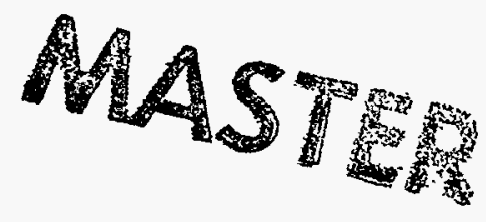

January 1997

Work sponsored by United States Department of Energy, Office of Environmental Restoration, Washington, DC and Richland Operations Office, Richland, Washington 


\section{DISCLAAMER}

Portions of this document may be illegible in electronic image products. Images are produced from the best available original document. 


\section{CONTENTS}

NOTATION V

ABSTRACT 1

1 INTRODUCTION AND BRIEF HISTORY $\ldots \ldots \ldots \ldots \ldots \ldots \ldots \ldots \ldots \ldots$

1.1 Site Description and Setting $\ldots \ldots \ldots \ldots \ldots \ldots \ldots \ldots \ldots \ldots \ldots \ldots \ldots \ldots \ldots, \ldots \ldots \ldots$

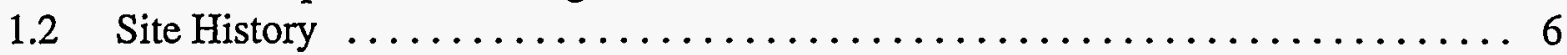

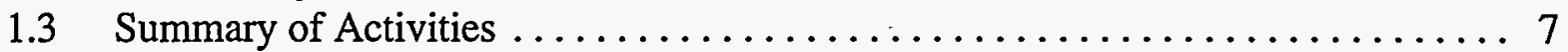

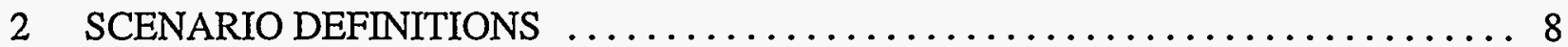

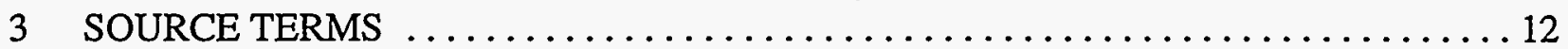

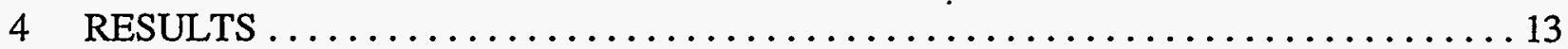

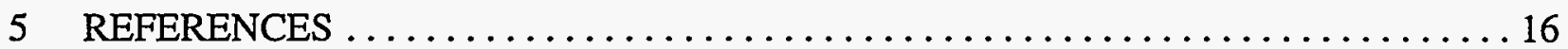

APPENDIX: Parameters Used for the Analysis of the Potential Radiation Doses from the Decontaminated Concrete Removed from the 183-H Solar Evaporation Basins at the Hanford Site .

\section{FIGURES}

1 Location of the Hanford Site, Richland, Washington $\ldots \ldots \ldots \ldots \ldots \ldots \ldots$

2 Location of the $183-\mathrm{H}$ Solar Evaporation Basins .................... 5

\section{TABLES}

1 Summary of Exposure Pathways Considered for Scenarios A, B, C, and D of the Decontaminated Concrete Removed from 183-H SEB

2 Radionuclide Concentrations Used in the RESRAD Code for Analysis of the Radiation Dose from Decontaminated Concrete Removed from 183-H SEB 


\section{TABLES (Cont.)}

3 Summary of the Potential Maximum Dose Rates for Scenarios A, B, C, and D of the Decontaminated Concrete Removed from 183-H SEB

A.1 Parameters Used in the RESRAD Computer Code for the Analysis of the Potential

Radiation Doses from the Decontaminated Concrete Removed from 183-H SEB 17 


\section{NOTATION}

The following is a list of the acronyms, initialisms, and abbreviations (including units of measure) used in this document. Some acronyms used only in tables or equations are defined in the respective tables or equations.

\section{ACRONYMS, INITIALISMS, AND ABBREVIATIONS}

$\begin{array}{ll}\text { DOE } & \text { U.S. Department of Energy } \\ \text { DOT } & \text { U.S. Department of Transportation } \\ \text { RCRA } & \text { Resource Conservation and Recovery Act } \\ \text { RESRAD } & \text { residual radioactive material guidelines computer code } \\ \text { SEB } & \text { Solar Evaporation Basin }\end{array}$

\section{UNITS OF MEASURE}

$\begin{array}{ll}\mathrm{cm}^{3} & \text { centimeter(s) } \\ \mathrm{cm}^{3} & \text { cubic centimeter(s) } \\ \mathrm{d} & \text { day(s) } \\ \mathrm{dpm} & \text { disintegrations per minute } \\ \mathrm{ft} & \text { foot (feet) } \\ \mathrm{g} & \text { gram(s) } \\ \mathrm{gal} & \text { gallon(s) } \\ \mathrm{h} & \text { hour(s) } \\ \mathrm{in.} & \text { inch(es) } \\ \mathrm{kg} & \text { kilogram(s) } \\ \mathrm{km} & \text { kilometer(s) } \\ \mathrm{km} & \text { square kilometer(s) } \\ \mathrm{L} & \text { liter(s) } \\ \mathrm{m} & \text { meter(s) } \\ \mathrm{m}^{2} & \text { square meter(s) } \\ \mathrm{m}^{3} & \text { cubic meter(s) } \\ \mathrm{mm} & \text { millimeter(s) } \\ \mathrm{mrem} & \text { millirem(s) } \\ \mathrm{pCi} & \text { picocurie(s) } \\ \mathrm{s} & \text { second(s) } \\ \mathrm{yd} & \text { cubic yard(s) } \\ \mathrm{yr} & \text { year(s) }\end{array}$




\title{
RADIOLOGICAL DOSE ASSESSMENT FOR THE DECONTAMINATED CONCRETE REMOVED FROM 183-H SOLAR EVAPORATION BASINS AT THE HANFORD SITE, RICHLAND, WASHINGTON
}

by

\author{
S. Kamboj, E. Faillace, and C. Yu
}

\begin{abstract}
Potential maximum radiation dose rates over a 1,000-year time horizon were calculated for exposure to the decontaminated concrete removed from the 183-H Solar Evaporation Basins at the Hanford Site, Richland, Washington. The RESRAD computer code, Version 5.62, which implements the methodology described in the U.S. Department of Energy's manual for developing residual radioactive material guidelines, was used in this evaluation. Currently, the concrete is not being used. Four potential exposure scenarios were developed for the land area where the decontaminated concrete will be stored; the seenarios vary with-regard-to-the-type-of tand use, time-spent,-and sourees-of foed consumed. In Scenario A (-a likely tand-use-seenario)-industrial use of the land is assumed; in Scenario B (a-likely-future-land-use-scenario), recreational use of the land is assumed; in Scenario C (atikety-future-tand-use-scenario), residential use of the land is assumed; and in Scenario D (a plausible but unlikely land-use scenario), the presence of a subsistence farmer in the immediate vicinity of the land is assumed. For Scenarios A and B, water used for drinking is assumed to be surface water from the Columbia River; for Scenarios C and D, groundwater drawn from a well located at the downgradient edge of the storage area is the only source of water for drinking, irrigation, and raising livestock. Conservative parameter values were used to estimate the radiation doses. The results of the evaluation indicate that the U.S. Department of Energy's dose limit of $100 \mathrm{mrem} / \mathrm{yr}$ would not be exceeded for any of the scenarios analyzed. The potential maximum dose rates for Scenarios A, B, C, and D are 0.75, 0.022, 29, and $29 \mathrm{mrem} / \mathrm{yr}$, respectively. An uncertainty analysis was performed to determine which parameters have the greatest impact on the estimated doses. The doses in Scenarios $C$ and $D$ were found to be very sensitive to the magnitude of the irrigation rate.
\end{abstract}





\section{INTRODUCTION AND BRIEF HISTORY}

The Hanford Site, acquired in 1943 , is a $1,450-\mathrm{km}^{2}$ reservation owned by the U.S. government and administered by the U.S. Department of Energy (DOE), Richland Operations Office. The Hanford Site is located in the Pasco Basin along the Columbia River in southeastern Washington and covers portions of Benton, Grant, Franklin, and Adams Counties (Figure 1). The Yakima River runs along part of the southern boundary and joins the Columbia River downstream from the city of Richland (Figure 1). The Hanford Site was initially dedicated to producing plutonium for national defense and managing the resulting wastes. In later years, programs were diversified to include research for advanced reactors, renewable energy technologies, waste disposal technologies, and cleanup of contamination from past practices. The site's current mission involves waste management, environmental restoration, scientific research, and technology development. The major operational areas on the site include (1) the 100 Area, located on the south shore of the Columbia River; (2) the 200-West and 200-East Areas, located on a plateau; (3) the 300 Area, located just north of the city of Richland; (4) the 400 Area, located northwest of the 300 Area; and (5) the 600 Area, which includes all of the Hanford Site not occupied by the 100, 200, 300, and 400 Areas (Figure 1).

The 183-H Solar Evaporation Basin (SEB) area is part of the 100-H Area and consists of a series of four basins (aboveground concrete structures) that were used from 1973 to 1985 for the treatment of liquid chemical wastes from the 300 Area fuel fabrication facilities. The 183-H SEB is a final-status treatment unit under the Resource Conservation and Recovery Act (RCRA), currently undergoing closure in accordance with Washington Administrative Code 173-303. The SEB is also within the geographic area encompassed by the 100-HR-1 Operable Unit, an area designated for remedial investigation under the Comprehensive Environmental Response, Compensation, and Liability Act. Structural concrete and soils are generated from the RCRA closure of the 183-H SEB.

The RESRAD computer code, Version 5.62, which implements the methodology described in DOE's manual for developing residual radioactive material guidelines (Yu et al. 1993a), was used to perform a dose assessment for the decontaminated concrete from the 183-H SEB.

\subsection{SITE DESCRIPTION AND SETTING}

The 183-H SEB is located in the northern part of the Hanford Site (Figure 2). The 100-H Area contained a nuclear-defense production reactor facility that operated from October 1949 to April 1965. The 183-H SEB consists of four basins that remain from operation of the 183-H Water Treatment Facility, which provided water treatment and reservoir capacity for the reactor's process water system. This water treatment plant operated concurrently with the start-up and shutdown of the 105-H Reactor. 


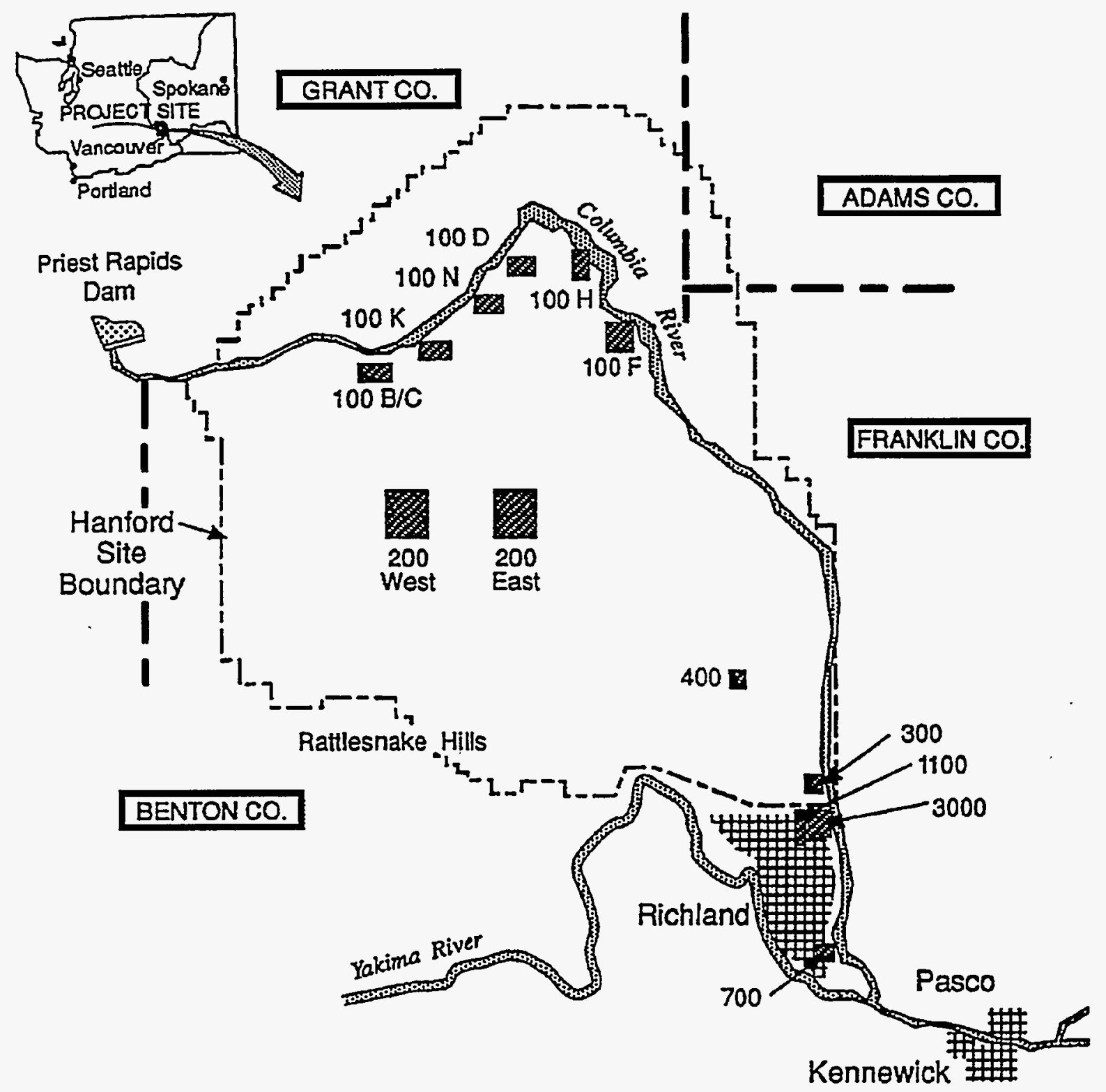

Note: The 600 Area consists of all portions of the Hanford Site not othenwise designated

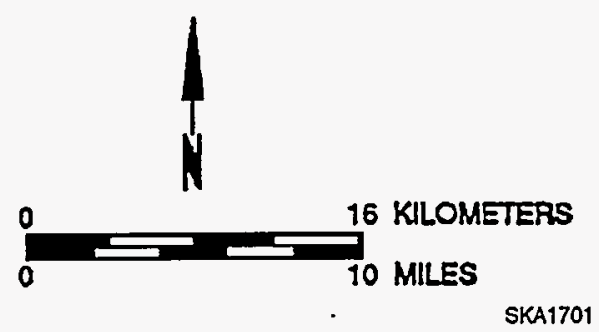

FIGURE 1 Location of the Hanford Site, Richland, Washington 


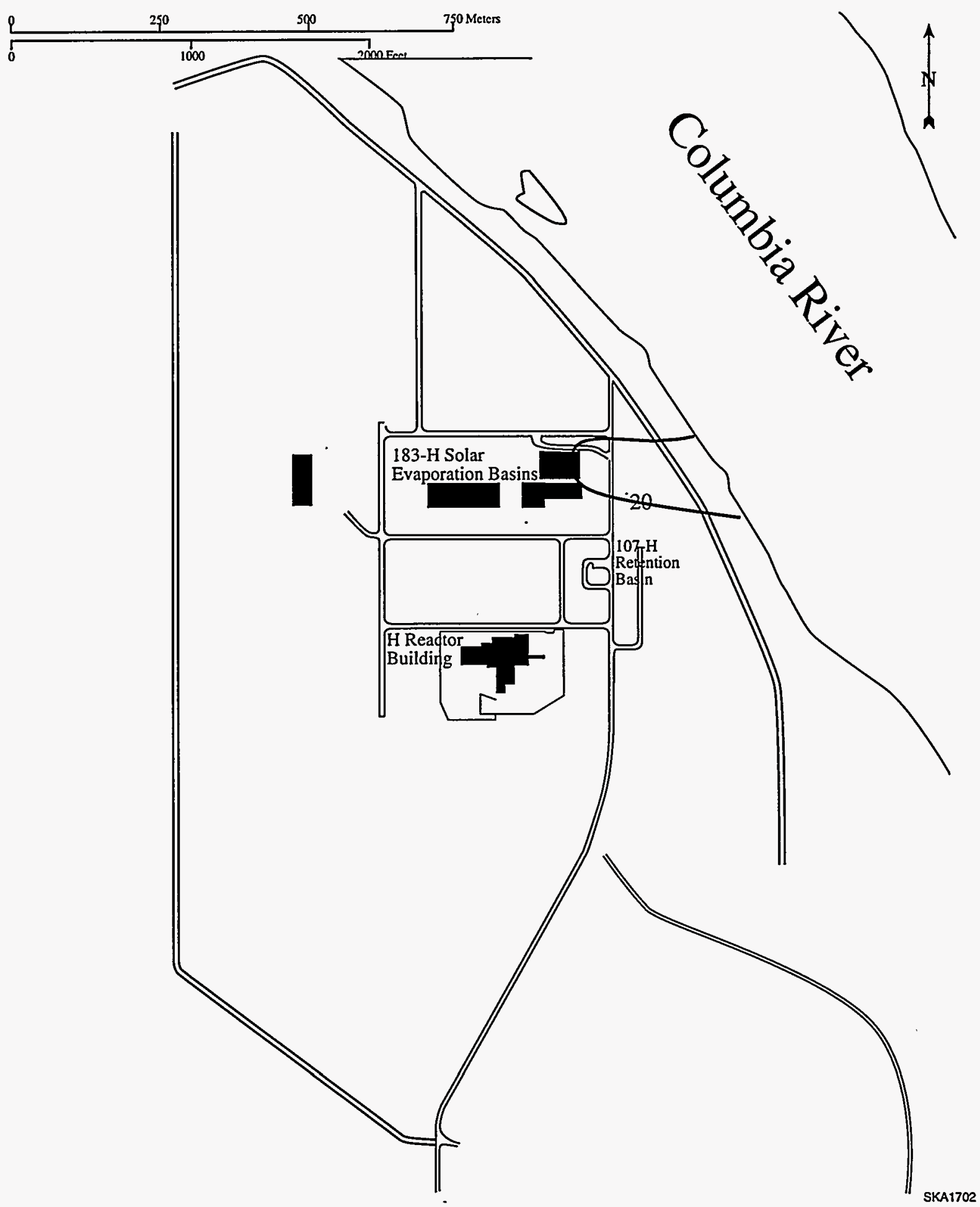

FIGURE 2 Location of the 183-H Solar Evaporation Basins 
The Hanford Site has a mid-latitude $\left(\approx 46^{\circ}\right)$, semiarid climate because of a rain shadow created by the Cascade Range, located approximately $130 \mathrm{~km}$ to the west. Fifteen different soil types are identified on the Hanford Site, varying from sand to silty and sandy loam. The most common soil type is Quincy/Rupert sand. To capture the regional heterogeneity associated with the Hanford Site, it has been divided into seven major hydrogeologic settings. The hydrogeologic setting information represents the partially saturated and saturated zones. For partially saturated zones, this information includes layer thickness, soil type (i.e., percent sand, silt, and clay), bulk density, total porosity, field capacity, saturated hydraulic conductivity, and longitudinal dispersivity. For the saturated zone, this information includes layer thickness, soil type, and bulk density. Settings for the 100-H Area, which has one partially saturated zone and one saturated zone, were used in this analysis (DOE 1996a).

Average precipitation at the Hanford Site is $16 \mathrm{~cm}$, and the average snowfall is $33 \mathrm{~cm}$. Little surface runoff occurs because of the generally flat topography and the limited precipitation. Most of the precipitation is returned to the atmosphere through evapotranspiration. Evapotranspiration levels vary greatly with location at the Hanford Site because of the differences in soil properties and the type and density of local vegetation. Wind speed and direction vary throughout the site because of the local influence of mountain ridges and river valleys. Average wind speeds at Hanford are 2.8 to $3.3 \mathrm{~m} / \mathrm{s}$ in winter and 3.6 to $4.7 \mathrm{~m} / \mathrm{s}$ in summer. The area surrounding the Hanford Site is predominantly rural farmland, with the exception of the cities of Kennewick, Pasco, and Richland.

\subsection{SITE HISTORY}

The 183-H Water Treatment Facility consisted of a headhouse and chemical building, a filter building and clean-water storage vaults (clear wells), a pump room, and 16 basins. Each of these basins was made up of a shallow flocculation basin and a deeper sedimentation basin. Most of the facility was demolished in 1974. Rubble from demolition was used as backfill in the nearby clear wells. Four basins were left intact and designated for use as a solar evaporation facility for chemical waste. The adjacent clear wells were also left intact for future use as a disposal site for clean debris. Each of the four remaining basins consisted of a flocculation reservoir and a sedimentation reservoir. The width of the concrete basins' walls was uniformly $15 \mathrm{~cm}$, and the minimum thickness of the basin floor was $13 \mathrm{~cm}$.

Beginning in 1973, Basin 1 was used for disposal of neutralized acid etching solutions from N Reactor fuel fabrication facilities in the 300 Area of the Hanford Site, as well as for miscellaneous used and unused chemicals. Waste deposited in the basins underwent volume reduction through evapotranspiration. The use of Basin 1 was discontinued in 1978. Spray-on polyurethane liners were installed in Basins 2 and 3, and then the liquid waste from Basin 1 was transferred into Basin 3 in 1978 (Basin 1 solids and sludge were removed in 1985). Basin 2 first managed waste in 1979. The use of Basin 4 started in 1982. The last shipment of waste to the basins occurred in November 1985. 
Before the implementation of initial RCRA closure activities in 1986, Basins 2, 3, and 4 held waste consisting of three distinct layers: (1) a basal crystalline layer, (2) an intermediate sludge layer, and (3) a liquid layer on the top. By using Sorbid LPC II colloidal cement, the liquid waste was solidified inside lined U.S. Department of Transportation (DOT) approved 17-H, 55-gal drums. The sludge and crystalline layers were removed from the basins by manually shoveling or scooping the material into lined DOT-approved 17-H, 55-gal drums. Basins 1 and 4 were subsequently cleaned by wet sandblasting. Waste generated during sandblasting was also packaged. The drums containing the liquids, solids, sludge, and sandblasting waste were sealed and taken to the Hanford Site Central Waste Complex Retrievable Waste Storage Unit. By the end of 1990, all bulk waste was removed from the 183-H basins.

Concrete in the 183-H SEB was exposed to waste chemical solutions containing low levels of slightly enriched uranium from the 300 Area fuel fabrication process. Radionuclides of concern are uranium-238, uranium-235, uranium-234, and technetium-99. Technetium is a concern because it tended to be concentrated through the fuel processing and enrichment process. Before decontamination of the basins, concrete samples obtained from each of the basins were analyzed for gross alpha and beta activity. Uranium isotopes were not determined; however, total uranium present was determined chemically.

The 183-H structural concrete was decontaminated through a scrabbling technology to remove the top $6 \mathrm{~mm}$ of contaminated surface. The remaining structural concrete at $183-\mathrm{H}$ was expected to contain little chemical contamination attributable to waste operations. The extraction technology utilized to clean the concrete is highly effective in the removal of both chemical and radiological constituents. However, the decontamination efforts did not remove $100 \%$ of the original contamination present on and in the concrete; some residual radioactive material was contained in the mass or volume of the concrete.

\subsection{SUMMARY OF ACTIVITIES}

Approximately $3,500 \mathrm{~m}^{3}$ of decontaminated rubble was generated during the remediation of the 183-H SEBs (Bruggeman 1996).

Samples were obtained from the 183- $\mathrm{H}$ basins on October 23, 1995, and again on November 1, 1995. An air-driven roto-hammer was used to grind off surface concrete from predetermined locations in Basins 1 through 4 to determine the extent of residual radioactive material. The samples were sent to the Environmental Analytical Laboratory for analysis. These samples were treated similarly to the pre-decontamination samples and were analyzed for gross alpha and beta activity, as well as by gamma-spectrometry. 


\section{SCENARIO DEFINITIONS}

Currently, the land area containing the decontaminated concrete (hereafter referred to as the storage area) from the 183-H SEB is not being used; however, for assessing radiation dose, four potential exposure scenarios were considered. For these scenarios, the assumption was that at some time within 1,000 years, the land area will be released for use without radiological restrictions. These scenarios were developed on the basis of discussion with the Hanford Site personnel to ensure consistency with the land-use scenarios discussed in the sitewide environmental impact statement for the Hanford Site. Potential radiation doses resulting from nine exposure pathways were considered for each scenario: (1) direct exposure to external radiation from the decontaminated concrete; (2) internal radiation from inhalation of potentially contaminated dust; (3) internal radiation from inhalation of emanating radon-222 from the decontaminated concrete and from household water; (4) internal radiation from ingestion of plant foods grown in the storage area; (5) internal radiation from ingestion of meat from livestock or game animals fed with fodder grown in the storage area; (6) internal radiation from ingestion of milk obtained from livestock fed with fodder grown in the storage area; (7) internal radiation from ingestion of fish from a surface water body located downgradient from the storage area; (8) internal radiation from incidental ingestion of decontaminated concrete; and (9) internal radiation from drinking water drawn from a nearby surface water source or well. Specific exposure pathways considered for the four scenarios (Scenarios A, B, $\mathrm{C}$, and $\mathrm{D}$ ) are summarized in Table 1.

Scenario A (a likely land-use scenario) assumes industrial use of the storage area land. Under this scenario, a hypothetical individual is assumed to work 8 hours per day at the storage area ( 6 hours working outdoors and 2 hours indoors), 5 days per week, 50 weeks per year. The worker is assumed to consume $250 \mathrm{~L}$ of surface water from the area in one year. The worker does not ingest plant foods or fish obtained from the storage area or meat or milk from livestock raised in the storage area. The dose to the worker is assumed to be from exposure to decontaminated concrete, inhalation of contaminated particulates or radon, and ingestion of contaminated surface water.

Scenario B (a likely future land-use scenario) assumes recreational use of the storage area. Under this scenario, the assumption is that, at some time in the future, a larger area which includes the storage area will be transformed into a public recreational park or forest preserve, and a hypothetical individual spends 50 hours of one week in the storage area of the park. Therefore, in one year, this generic recreationist was assumed to spend $0.6 \%$ of the time in the storage area and $99.4 \%$ away from the storage area. The recreationist is assumed to ingest $14 \mathrm{~L}$ of water drawn from nearby surface water. Neither plant foods obtained from the storage area nor meat or milk from livestock raised in the storage area is consumed by the recreationist. However, some of the meat (game animals), fish, or aquatic food consumed by the recreationist is obtained from the storage area. For the sake of conservatism, the radionuclide concentrations in the tissue of the game animals are assumed to be the same as in cattle raised in the storage area. 
TABLE 1 Summary of Exposure Pathways Considered for Scenarios A, B, C, and D of the Decontaminated Concrete Removed from 183-H SEB

\begin{tabular}{lcccc}
\hline \multicolumn{1}{c}{ Pathway } & Scenario $\mathrm{A}^{\mathrm{a}}$ & ${\text { Scenario } \mathrm{B}^{\mathrm{b}}}$ & ${\text { Scenario } \mathrm{C}^{\mathrm{c}}}$ & Scenario D $^{\mathrm{d}}$ \\
\hline External gamma exposure & & & & \\
Inhalation of dust & Yes & Yes & Yes & Yes \\
Inhalation of radon & Yes & Yes & Yes & Yes \\
Ingestion of plant foods & Yes & Yes & Yes & Yes \\
Ingestion of meat & No & No & Yes & Yes \\
Ingestion of milk & No & Yes & No & Yes \\
Ingestion of fish & No & No & No & Yes \\
Ingestion of concrete & No & Yes & Yes & Yes \\
Ingestion of water & Yes & Yes & Yes & Yes \\
\hline
\end{tabular}

a Industrial worker: no consumption of food obtained from the storage area, and the water used for drinking is from the Columbia River (the nearby surface water).

b Recreationist: no consumption of food except meat (game animals) and fish obtained from the storage area, and the water used for drinking is from the Columbia River (the nearby surface water).

c Resident: no consumption of meat and milk obtained from the storage area, and the water used for drinking, irrigation, and household uses is from a well in that area.

d Subsistence farmer: water used for drinking, household purposes, irrigation, and livestock watering is from a local well in the storage area.

e Ingested water for the industrial worker and recreationist is from the Columbia River, which sometime in the near future is assumed to be contaminated by the leachate from the storage area as the leachate transports to the groundwater and is then taken up by the river. Because RESRAD considers surface water as a lake or pond, to account for the more dynamic flowing situation of a river (which would result in more dilution of contaminants), a large watershed area equal to the area of the Pasco Basin was assumed in order to account for the large dilution in the Columbia River.

Scenario C (a likely future land-use scenario) assumes residential use of the area. The assumption is that at some time in the future, an area containing the storage area will be transformed into a residential area. Under this scenario, in one year a hypothetical resident is assumed to spend $50 \%$ of the time indoors in the storage area, $25 \%$ of the time outdoors in the storage area, and $25 \%$ of the time away from the area. The resident is assumed to ingest plant foods grown in a garden in the area. All water used by the resident for drinking, irrigation, and household purposes is from a well located within the area. For this scenario, the assumption is that no livestock are raised for the production of meat and milk; however, a nearby surface water body is present to provide fish or other aquatic food. 
Scenario D (a plausible but unlikely future land-use scenario) is similar to Scenario C, in which a resident is assumed to ingest plant foods grown in the garden. However, under Scenario D, the resident is assumed to be a subsistence farmer who would ingest meat and milk from livestock raised in the area and consume fish and other aquatic organisms caught from nearby surface water. For this scenario, the groundwater drawn from a local well is the only water source for drinking, household use, irrigation, and livestock watering.

The RESRAD computer code, Version 5.62 (Yu et al. 1993a), was used to calculate the potential radiation doses for the hypothetical future industrial worker (Scenario A), recreationist (Scenario B), resident (Scenario C), and subsistence farmer (Scenario D) on the basis of the following assumptions:

- During one year, the industrial worker spends 1,500 hours $(17 \%$ of his or her time) outdoors at the storage area, 500 hours (6\%) indoors at the storage area, and 6,760 hours (77\%) away from the area; the recreationist spends 50 hours $(0.6 \%)$ in the storage area and 8,710 hours (99.4\%) away from the area. During one year, the resident and subsistence farmer (Scenarios C and D) spend 4,380 hours $(50 \%)$ indoors, 2,190 hours $(25 \%)$ outdoors in the storage area, and 2,190 hours (25\%) away from the area (Yu et al. 1993a).

- The total storage area is $940 \mathrm{~m}^{2}$, with a density of $2.4 \mathrm{~g} / \mathrm{cm}^{3}$ and a porosity of 0.1 .

- The well pumping rate is assumed to be $550 \mathrm{~m}^{3} / \mathrm{yr}$. This pumping rate would be sufficient to provide enough water for irrigation, drinking, and other household uses.

- The irrigation rate is assumed to be $0.5 \mathrm{~m} / \mathrm{yr}$ because the climate at the Hanford Site is semiarid, and there is very little precipitation.

- The walls, floor, and foundation of the house (Scenarios C and D) or commercial building (Scenario A) reduce external exposure by $30 \%$. The indoor dust level is $40 \%$ of the outdoor dust level (Yu et al. 1993a).

- The depth of the house or building foundation is set to maximize the radon inhalation dose, but not to exceed $1 \mathrm{~m}$ below the ground surface (RESRAD default -1), with an effective radon diffusion coefficient of $3 \times 10^{-7} \mathrm{~m}^{2} / \mathrm{s}(\mathrm{Yu}$ et al. 1993a).

- The plant food diet consumed by the resident (Scenario C) and the subsistence farmer (Scenario D) is taken from the Health Risk Assessment Methodology 
for the Hanford Site (DOE 1995). To account for the small area of contamination, the area factor methodology in RESRAD is used to estimate the contaminated fraction of the consumed food. Of the plant diet consumed by the resident and the subsistence farmer, $47 \%$ is estimated to be contaminated. The industrial worker (Scenario A) and recreationist (Scenario B) do not consume these plant foods.

- The amount of meat consumed by the recreationist in Scenario B and the meat and milk consumed by the subsistence farmer in Scenario $D$ are taken from the Health Risk Assessment Methodology for the Hanford Site (DOE 1995). To account for the small area of contamination, the area factor methodology in RESRAD is used to estimate the contaminated fraction of the consumed food. Of the meat and milk consumed by the recreationist and the subsistence farmer, $4.7 \%$ is estimated to be contaminated. The industrial worker in Scenario $\mathrm{A}$ and the resident in Scenario $\mathrm{C}$ do not consume these animal products.

- For Scenarios B, C, and D, 50\% of the fish and other aquatic food consumed by the recreationist, resident, and subsistence farmer is assumed to be obtained from a nearby surface water body.

- After remedial action, $1 \mathrm{~m}$ of cover material will be placed over the storage area. Dose estimates do not take credit for the cover material and therefore are very conservative.

- The supply of water for the industrial use scenario (Scenario A) is from the Columbia River; this source is also assumed for Scenario B. However, for Scenarios $C$ and $D$, the source of water for drinking, household uses, and livestock watering is assumed to be a local well.

- The area for the Pasco Basin was estimated to be greater than $4.5 \times 10^{9} \mathrm{~m}^{2}$ (DOE 1996a) and was used as the watershed area for the surface water (the Columbia River) in Scenarios A and B.

- Site-specific parameters were used for the drinking water intake, soil ingestion rate, inhalation rate, well pump intake depth, water table drop rate, food consumption rates (except aquatic food), storage times (leafy vegetables, milk, fish, crustacea, and mollusks), evapotranspiration coefficient, precipitation rate, irrigation, runoff coefficient, saturated zone, and unsaturated zone.

- All other parameters are RESRAD defaults. 


\section{SOURCE TERMS}

The source term concentrations used in the RESRAD computer code were calculated with data collected after decontamination (i.e., removal of top 6-mm layer of concrete). Samples were obtained from the scrabbled walls and were sent to the Environmental Analytical Laboratory for analysis. Eight samples were analyzed for radioactive components. Table 2 gives the recommended residual concentrations of Tc-99, U-234, U-235, and U-238 to be used in RESRAD analysis (Brich 1996). The average background concentrations are based on the sitewide background data (DOE 1996b). The average radionuclide concentrations were used in this assessment (background concentrations were subtracted). The various parameters used in the RESRAD code are listed in the Appendix.

TABLE 2 Radionuclide Concentrations Used in the RESRAD Code for Analysis of the Radiation Dose from Decontaminated Concrete Removed from 183-H SEB

\begin{tabular}{|c|c|c|c|}
\hline Radionuclide & $\begin{array}{c}\text { Average } \\
\text { Radionuclide } \\
\text { Concentration }{ }^{\mathrm{a}} \\
(\mathrm{pCi} / \mathrm{g})\end{array}$ & $\begin{array}{l}\text { Average Background } \\
\text { Radionuclide } \\
\text { Concentration } \\
\text { (pCi/g) }\end{array}$ & $\begin{array}{c}\text { Radionuclide } \\
\text { Concentration Used } \\
\text { in RESRAD } \\
(\mathrm{pCi} / \mathrm{g})\end{array}$ \\
\hline Uranium-238 & 5.96 & 0.763 & 5.2 \\
\hline Uranium-234 ${ }^{d}$ & 5.96 & 0.793 & 5.2 \\
\hline Uranium-235 & 0.274 & 0.0515 & 0.22 \\
\hline Actinium $-227^{\mathrm{e}}$ & 0.274 & 0.0515 & 0.22 \\
\hline Protactinium-231 ${ }^{\mathrm{e}}$ & 0.274 & 0.0515 & 0.22 \\
\hline Technetium-99 & 27.0 & 0.0 & 27.0 \\
\hline
\end{tabular}

a Average radionuclide concentrations are calculated from Brich (1996).

b Source: DOE (1996b).

c The background radionuclide concentration is subtracted from the average radionuclide concentration.

${ }^{d}$ Uranium-238 and uranium-234 radionuclide concentrations are based on natural uranium abundances and are calculated from uranium-235 radionuclide concentration data. In actuality, the concrete became contaminated from enriched uranium. Uranium-238 activities were all reported to be below detection limits. Therefore, this assumption is conservative.

e Concentration based on the assumption that the radionuclide is in secular equilibrium with uranium-235. 


\section{RESULTS}

The RESRAD computer code, Version 5.62, was used to calculate the potential radiation doses for each exposure scenario. The time frame considered in this analysis was 1,000 years. Radioactive decay and ingrowth were considered in calculating the maximum dose rates. The various parameters used in the RESRAD code for this analysis are listed in the Appendix. The calculated maximum dose rates for Scenarios A, B, C, and D are presented in Table 3.

For all scenarios, the maximum dose rate does not exceed the DOE annual limit of $100 \mathrm{mrem} / \mathrm{yr}$ (DOE 1990, 1992).The maximum dose rate for Scenario A (industrial worker) would occur at 1,000 years after the post-decontamination survey and is due to the radon buildup over time. The total dose changes from $0.70 \mathrm{mrem} / \mathrm{yr}$ at time zero to $0.75 \mathrm{mrem} / \mathrm{yr}$ at 1,000 years. For Scenario B (recreationist), the maximum dose of $0.022 \mathrm{mrem} / \mathrm{yr}$ occurs at time zero (the year in which the radiological survey was conducted). For Scenarios C (resident) and D (subsistence farmer), the time at which the maximum dose rate would occur is 25 years following the post-decontamination survey and is due to the Tc-99 water pathway dose.

For Scenario A (industrial worker), dust inhalation, external gamma exposure, and radon inhalation are the dominant pathways, contributing approximately $46 \%, 32 \%$, and $14 \%$, respectively, of the total annual dose. For Scenario B (recreationist), the dust inhalation and external gamma exposure are the dominant pathways, contributing approximately $55 \%$ and $34 \%$, respectively, of the total annual dose. For Scenarios C and D, the maximum dose rates are $29 \mathrm{mrem} / \mathrm{yr}$. Ingestion of water and plant foods accounts for about $79 \%$ and $13 \%$, respectively, of the total annual dose.

Several conservative assumptions were made in all scenarios. These assumptions would all result in an overestimation of the calculated doses. The first assumption is the absence of clean cover material above the decontaminated concrete. The $1 \mathrm{~m}$ of cover material above the concrete, if undisturbed, would result in effectively zero dose at time zero because such a thick cover would be sufficient to shield the gamma radiation from the concrete. This cover thickness is six times greater than the assumed thickness of the mixing layer and is slightly greater than the assumed root depth of plants; therefore, all inhalation and ingestion doses would be zero at time zero.

Another conservative assumption is the uniform distribution of radionuclides within the concrete and the assumption that the concrete has not been broken up. Concentrations below the concrete surface are likely to be lower than the concentrations at the surface. Also, the concrete has been broken up into pieces, and soil from the clean cover would be expected to fill some of the voids. This would result in a lower overall radionuclide concentration in the contaminated zone. All calculated doses are directly proportional to the concentrations. 
TABLE 3 Summary of the Potential Maximum Dose Rates for Scenarios A, B, C, and D of the Decontaminated Concrete Removed from 183-H SEB

\begin{tabular}{lcccc}
\hline & \multicolumn{4}{c}{ Potential Maximum Dose Rate (mrem/yr) } \\
\cline { 2 - 5 } \multicolumn{1}{c}{ Pathway } & Scenario A & Scenario B $^{\mathrm{b}}$ & Scenario C $^{\mathrm{c}}$ & Scenario D $^{\mathrm{c}}$ \\
\hline & & & & \\
External gamma exposure & $2.5 \times 10^{-1}$ & $7.4 \times 10^{-3}$ & $7.4 \times 10^{-1}$ & $7.4 \times 10^{-1}$ \\
Inhalation & & & & \\
Dust & $3.6 \times 10^{-1}$ & $1.2 \times 10^{-2}$ & $9.2 \times 10^{-1}$ & $9.2 \times 10^{-1}$ \\
Radon & $1.1 \times 10^{-1}$ & 0.0 & $7.5 \times 10^{-4}$ & $7.5 \times 10^{-4}$ \\
Ingestion & & & & \\
Plant foods & $\mathrm{NA}^{\mathrm{d}}$ & $\mathrm{NA}$ & 3.9 & 3.9 \\
Meat & $\mathrm{NA}$ & $7.4 \times 10^{-5}$ & $\mathrm{NA}$ & $2.0 \times 10^{-2}$ \\
Milk & $\mathrm{NA}$ & $\mathrm{NA}$ & $\mathrm{NA}$ & $7.8 \times 10^{-2}$ \\
Fish & $\mathrm{NA}$ & 0.0 & $3.3 \times 10^{-1}$ & $3.3 \times 10^{-1}$ \\
Concrete & $3.0 \times 10^{-2}$ & $2.1 \times 10^{-3}$ & $2.6 \times 10^{-1}$ & $2.6 \times 10^{-1}$ \\
$\quad$ Water & 0.0 & 0.0 & $2.3 \times 10^{1}$ & $2.3 \times 10^{1}$ \\
Total & $7.5 \times 10^{-1}$ & $2.2 \times 10^{-2}$ & $2.9 \times 10^{1}$ & $2.9 \times 10^{1}$ \\
\hline
\end{tabular}

a Maximum dose for Scenario A (industrial worker) would occur 1,000 years after the postdecontamination survey.

b Maximum dose for Scenario B (recreationist) would occur at time zero.

c Maximum dose for Scenario C (resident) and Scenario D (subsistence farmer) would occur 25 years after the post-decontamination survey.

d NA = not applicable because it is not a pathway of concern.

e Source of water used: Columbia River water is used for drinking in Scenarios A and B, and 100\% well water is used for drinking, household uses, and irrigation in Scenarios C and D (also used for livestock watering in Scenario D).

The assumption that plants could easily grow in the decontaminated concrete is also unlikely because this material has not been broken down into soil-sized particles. As a result, the ingestion of contaminated plant foods grown in the storage area and the ingestion by livestock of the contaminated fodder grown in the storage area are unlikely to occur. If plants grow in the storage area, the plant roots would be expected to preferentially penetrate soil-filled cracks between the concrete pieces; therefore, a smaller radionuclide inventory would be available for root uptake. For these reasons, the radiation doses calculated for the plant, meat, and milk pathways are overestimated. 
An uncertainty analysis was performed to determine which parameters have the greatest impact on the estimated doses. The doses in Scenarios $C$ and $D$ were found to be very sensitive to the magnitude of the irrigation rate. The irrigation rate was given a triangular distribution, with a minimum of $0.2 \mathrm{~m} / \mathrm{yr}$ (the RESRAD default for humid regions), a most likely value of $0.5 \mathrm{~m} / \mathrm{yr}$, and a maximum value of $1 \mathrm{~m} / \mathrm{yr}$. The well pumping rate was correlated to match the irrigation rate. The peak dose was found to be proportional to the irrigation rate, ranging from about 20 to $39 \mathrm{mrem} / \mathrm{yr}$, with an average of $31 \mathrm{mrem} / \mathrm{yr}$. Peak dose times were inversely correlated with irrigation rate, ranging from 40 to 17 years following remediation, with an average of 24 years. A deterministic run was performed by selecting a likely value for irrigation of $0.5 \mathrm{~m} / \mathrm{yr}$, resulting in the reported doses for Scenarios $C$ and D. In the absence of irrigation, a peak dose of $11 \mathrm{mrem} / \mathrm{yr}$ at 95 years following remediation was calculated for Scenario $D$. 


\section{REFERENCES}

Brich, R., 1996, Fax from Brich (Hanford Site, Richland, Wash.), to C. Yu (Argonne National Laboratory, Argonne, Ill.), June 30.

Bruggeman, J.M., 1996, personal communication from Bruggeman (Project Manager, D\&D, Richland Operations Office) to C. Yu (Argonne National Laboratory, Argonne, Ill.), Feb. 26.

DOE: See U.S. Department of Energy

U.S. Department of Energy, 1990, "Radiation Protection of the Public and Environment," DOE Order 5400.5, Washington, D.C., Feb. 8.

U.S. Department of Energy, 1992, Radiological Control Manual, Assistant Secretary for Environment, Safety, and Health, Washington, D.C., June.

U.S. Department of Energy, 1995, Hanford Site Risk Assessment Methodology, DOE/RL-91-45, May.

U.S. Department of Energy, 1996a, Hanford Remedial Action Environmental Impact Statement, DOE/EIS-0222, Feb.

U.S. Department of Energy, 1996b, Hanford Site Background: Part 2. Soil Background for Radionuclides, DOE/RL-96-12, March.

Yu, C., et al., 1993a, Manual for Implementing Residual Radioactive Material Guidelines Using RESRAD, Version 5.0, ANL/EAD/LD-2, prepared by Argonne National Laboratory, Environmental Assessment Division, Argonne, Ill., for U.S. Department of Energy, Office of Environmental Restoration, Washington, D.C., Sept.

Yu, C., et al., 1993b, Data Collection Handbook to Support Modeling the Impacts of Radioactive Material in Soil, ANL/EAIS-8, prepared by Argonne National Laboratory, Environmental Assessment Division, Argonne, Ill., for U.S. Department of Energy, Office of Environmental Restoration, Washington, D.C., April. 


\section{APPENDIX}

\section{PARAMETERS USED FOR THE ANALYSIS OF THE POTENTIAL RADIATION DOSES FROM THE DECONTAMINATED CONCRETE REMOVED FROM THE 183-H SOLAR EVAPORATION BASINS AT THE HANFORD SITE}

The parametric values used in the RESRAD code for the analysis of the radiation doses from the decontaminated concrete removed from the 183-H basins are listed in Table A.1. All parametric values are reported at up to three significant figures. Some values are specific to the site; others are generic.

TABLE A.1 Parameters Used in the RESRAD Computer Code for the Analysis of the Potential Radiation Doses from the Decontaminated Concrete Removed from 183-H SEB

\begin{tabular}{|c|c|c|c|c|c|}
\hline \multirow[b]{2}{*}{ Parameter } & \multirow[b]{2}{*}{ Unit } & \multicolumn{4}{|c|}{ Value } \\
\hline & & Scenario A & Scenario B & Scenario C & Scenario D \\
\hline Area of contaminated zone $\mathrm{a}^{\mathrm{a}}$ & $\mathrm{m}^{2}$ & 940 & 940 & 940 & 940 \\
\hline Thickness of contaminated zone $\mathrm{e}^{\mathrm{a}}$ & $\mathrm{m}$ & 3.8 & 3.8 & 3.8 & 3.8 \\
\hline Length parallel to aquifer flow ${ }^{a}$ & $\mathrm{~m}$ & 31 & 31 & 31 & 31 \\
\hline Initial principal radionuclide concentration ${ }^{a}$ & $\mathrm{pCi} / \mathrm{g}$ & & & & \\
\hline Actinium-227 & & 0.22 & 0.22 & 0.22 & 0.22 \\
\hline Protactinium-231 & & 0.22 & 0.22 & 0.22 & 0.22 \\
\hline Technetium-99 & & 27.0 & 27.0 & 27.0 & 27.0 \\
\hline Uranium-234 & & 5.2 & 5.2 & 5.2 & 5.2 \\
\hline Uranium-235 & & 0.22 & 0.22 & 0.22 & 0.22 \\
\hline Uranium-238 & & 5.2 & 5.2 & 5.2 & 5.2 \\
\hline Cover depth ${ }^{b}$ & $\mathbf{m}$ & 0 & 0 & 0 & 0 \\
\hline \multicolumn{6}{|l|}{ Contaminated zone } \\
\hline Density ${ }^{\mathrm{a}}$ & $\mathrm{g} / \mathrm{cm}^{3}$ & 2.4 & 2.4 & 2.4 & 2.4 \\
\hline Erosion rate ${ }^{a}$ & $\mathrm{~m} / \mathrm{yr}$ & 0 & 0 & 0 & 0 \\
\hline Total porosity ${ }^{a}$ & $-c$ & 0.1 & 0.1 & 0.1 & 0.1 \\
\hline Effective porosity ${ }^{\mathfrak{a}}$ & - & 0.05 & 0.05 & 0.05 & 0.05 \\
\hline Hydraulic conductivity ${ }^{\mathrm{a}}$ & $\mathrm{m} / \mathrm{yr}$ & 4500 & 4500 & 4500 & 4500 \\
\hline Soil-specific $b$ parameter ${ }^{a}$ & - & 4.05 & 4.05 & 4.05 & 4.05 \\
\hline Evapotranspiration coefficient ${ }^{a}$ & - & 0.9 & 0.9 & 0.9 & 0.9 \\
\hline Precipitation ${ }^{\mathrm{a}}$ & $\mathrm{m} / \mathrm{yr}$ & 0.161 & 0.161 & 0.161 & 0.161 \\
\hline Irrigation $^{3}$ & $\mathrm{~m} / \mathrm{yr}$ & 0.5 & 0.5 & 0.5 & 0.5 \\
\hline Irrigation mode ${ }^{b}$ & - & Overhead & Overhead & Overhead & Overhead \\
\hline Runoff coefficient $t^{a}$ & - & 0.03 & 0.03 & 0.03 & 0.03 \\
\hline Watershed area for nearby pond $d^{3, b}$ & $\mathrm{~m}^{2}$ & $4,500,000,000$ & $4,500,000,000$ & $1,000,000$ & $1,000,000$ \\
\hline Accuracy for water/soil computation ${ }^{b}$ & - & 0.001 & 0.001 & 0.001 & 0.001 \\
\hline
\end{tabular}


TABLE A.1 (Cont.)

\begin{tabular}{|c|c|c|c|c|c|}
\hline \multirow[b]{2}{*}{ Parameter } & \multirow[b]{2}{*}{ Unit } & \multicolumn{4}{|c|}{ Value } \\
\hline & & Scenario A & Scenario B & Scenario C & Scenario D \\
\hline \multicolumn{6}{|l|}{ Saturated zone } \\
\hline Density $^{\mathrm{a}}$ & $\mathrm{g} / \mathrm{cm}^{3}$ & 1.64 & 1.64 & 1.64 & 1.64 \\
\hline Total porosity ${ }^{\mathrm{a}}$ & - & 0.38 & 0.38 & 0.38 & 0.38 \\
\hline Effective porosity ${ }^{2}$ & - & 0.26 & 0.26 & 0.26 & 0.26 \\
\hline Hydraulic conductivity ${ }^{3}$ & $\mathrm{~m} / \mathrm{yr}$ & 4,500 & 4,500 & 4,500 & 4,500 \\
\hline Hydraulic gradient ${ }^{a}$ & - & 0.001 & 0.001 & 0.001 & 0.001 \\
\hline Soil-specific b parameter ${ }^{2}$ & - & 4.05 & 4.05 & 4.05 & 4.05 \\
\hline Water table drop rate ${ }^{\mathfrak{a}}$ & $\mathrm{m} / \mathrm{yr}$ & 0.022 & 0.022 & 0.022 & 0.022 \\
\hline Well pump intake depth (below water table) ${ }^{a}$ & $\mathrm{~m}$ & 25 & 25 & 25 & 25 \\
\hline $\begin{array}{l}\text { Model: nondispersion (ND) or mass } \\
\text { balance }(\mathrm{MB})^{\mathrm{b}}\end{array}$ & - & ND & ND & ND & ND \\
\hline Well pumping rate ${ }^{a}$ & $\mathrm{~m}^{3} / \mathrm{yr}$ & 550 & 550 & 550 & 550 \\
\hline Number of unsaturated zone strata ${ }^{a}$ & - & 1 & 1 & 1 & 1 \\
\hline \multicolumn{6}{|l|}{ Unsaturated zone 1} \\
\hline Thickness $^{\mathrm{a}}$ & $\mathrm{m}$ & 13 & 13 & 13 & 13 \\
\hline Soil density ${ }^{2}$ & $\mathrm{~g} / \mathrm{cm}^{3}$ & 1.64 & 1.64 & 1.64 & 1.64 \\
\hline Total porosity ${ }^{a}$ & - & 0.38 & 0.38 & 0.38 & 0.38 \\
\hline Effective porosity ${ }^{\mathrm{a}}$ & - & 0.305 & 0.305 & 0.305 & 0.305 \\
\hline Soil-specific b parameter ${ }^{a}$ & - & 4.05 & 4.05 & 4.05 & 4.05 \\
\hline Hydraulic conductivity $^{\mathfrak{a}}$ & $\mathrm{m} / \mathrm{yr}$ & 4,500 & 4,500 & 4,500 & 4,500 \\
\hline Distribution coefficient $t^{\mathrm{a}, \mathrm{b}}$ & $\mathrm{cm}^{3} / \mathrm{g}$ & & & & \\
\hline \multicolumn{6}{|l|}{ Contaminated and unsaturated zone } \\
\hline Uranium-234 & & 100 & 100 & 100 & 100 \\
\hline Uranium-235 & & 100 & 100 & 100 & 100 \\
\hline Uranium-238 & & 100 & 100 & 100 & 100 \\
\hline Actinium-227 & & 50 & 50 & 50 & 50 \\
\hline Protactinium-231 & & 50 & 50 & 50 & 50 \\
\hline Lead-210 & & 100 & 100 & 100 & 100 \\
\hline Technetium-99 & & 0 & 0 & 0 & 0 \\
\hline Radium-226 & & 30 & 30 & 30 & 30 \\
\hline Thorium-230 & & 50 & 50 & 50 & 50 \\
\hline \multicolumn{6}{|l|}{ Saturated zone } \\
\hline Uranium-234 & & 100 & 100 & 100 & 100 \\
\hline Uranium-235 & & 100 & 100 & 100 & 100 \\
\hline Uranium-238 & & 100 & 100 & 100 & 100 \\
\hline Actinium-227 & & 50 & 50 & 50 & 50 \\
\hline Protactinium-231 & & 50 & 50 & 50 & 50 \\
\hline Lead-210 & & 100 & 100 & 100 & 100 \\
\hline Technetium-99 & & 0 & 0 & 0 & 0 \\
\hline Radium-226 & & 20 & 20 & 20 & 20 \\
\hline Thorium-230 & & 50 & 50 & 50 & 50 \\
\hline Inhalation rate $\mathrm{e}^{\mathrm{a}}$ & $\mathrm{m}^{3} / \mathrm{yr}$ & 7,300 & 7,300 & 7,300 & 7,300 \\
\hline Mass loading for inhalation ${ }^{\mathrm{a}}$ & $\mathrm{g} / \mathrm{m}^{3}$ & 0.0001 & 0.0001 & 0.0001 & 0.0001 \\
\hline Shielding factor, inhalation ${ }^{b}$ & - & 0.4 & 0.4 & 0.4 & 0.4 \\
\hline
\end{tabular}




\begin{tabular}{|c|c|c|c|c|c|}
\hline \multirow[b]{2}{*}{ Parameter } & \multirow[b]{2}{*}{ Unit } & \multicolumn{4}{|c|}{ Value } \\
\hline & & Scenario A & Scenario B & Scenario C & Scenario D \\
\hline Shielding factor, external gamma ${ }^{b}$ & - & 0.7 & 0.7 & 0.7 & 0.7 \\
\hline Fraction of time indoors $\mathrm{s}^{\mathrm{a}, \mathrm{b}}$ & - & 0.06 & 0.0 & 0.5 & 0.5 \\
\hline Fraction of time outdoors $\mathrm{s}^{\mathrm{a}, \mathrm{b}}$ & - & 0.17 & 0.006 & 0.25 & 0.25 \\
\hline Shape factor, external gamma ${ }^{b}$ & - & 1 & 1 & 1 & 1 \\
\hline Dilution length for airborne dust, inhalation ${ }^{b}$ & $\mathrm{~m}$ & 3 & 3 & 3 & 3 \\
\hline \multicolumn{6}{|l|}{ Food consumption } \\
\hline Fruits, vegetables, and grain ${ }^{2}$ & $\mathrm{~kg} / \mathrm{yr}$ & Not used & Not used & 15.33 & 15.33 \\
\hline Leafy vegetables ${ }^{a}$ & $\mathrm{~kg} / \mathrm{yr}$ & Not used & Not used & 29.2 & 29.2 \\
\hline Milk $^{\mathbf{a}}$ & L/yr & Not used & Not used & Not used & 109.5 \\
\hline Meat and poultry ${ }^{a}$ & $\mathrm{~kg} / \mathrm{yr}$ & Not used & 0.1 & Not used & 27.4 \\
\hline Fish $^{2}$ & $\mathrm{~kg} / \mathrm{yr}$ & Not used & 19.7 & 19.7 & 19.7 \\
\hline Other aquatic food $\mathrm{d}^{a, b}$ & $\mathrm{~kg} / \mathrm{yr}$ & Not used & 0.9 & 0.9 & 0.9 \\
\hline Soil ingestion ${ }^{\mathrm{a}}$ & $\mathrm{g} / \mathrm{yr}$ & 18.3 & 43.8 & 43.8 & 43.8 \\
\hline Drinking water intake ${ }^{\mathrm{a}}$ & L/yr & 250 & 14 & 730 & 730 \\
\hline Contaminated fraction of food and water & - & & & & \\
\hline Drinking water ${ }^{\mathrm{a}, \mathrm{b}}$ & & 1 & 1 & 1 & 1 \\
\hline Household water ${ }^{a, b}$ & & 1 & 1 & 1 & 1 \\
\hline Livestock water ${ }^{\text {a,b }}$ & & Not used & 1 & Not used & 1 \\
\hline Irrigation water ${ }^{\mathbf{a}, \mathrm{b}}$ & & 1 & 1 & 1 & 1 \\
\hline Aquatic food $d^{a, b}$ & & Not used & 0.5 & 0.5 & 0.5 \\
\hline Plant food $d^{a, b}$ & & Not used & Not used & $-1^{d}$ & $-1^{d}$ \\
\hline Meat ${ }^{a, b}$ & & Not used & $-1^{d}$ & Not used & $-1^{d}$ \\
\hline Milk $^{\mathrm{a}, \mathrm{b}}$ & & Not used & Not used & Not used & $-1^{d}$ \\
\hline Livestock fodder intake for meat ${ }^{a, b}$ & $\mathrm{~kg} / \mathrm{d}$ & Not used & 68 & Not used & 68 \\
\hline Livestock fodder intake for milk ${ }^{a, b}$ & $\mathrm{~kg} / \mathrm{d}$ & Not used & Not used & Not used & 55 \\
\hline Livestock water intake for meat ${ }^{\mathbf{a}, \mathrm{b}}$ & $L / d$ & Not used & 50 & Not used & 50 \\
\hline Livestock water intake for milk ${ }^{a, b}$ & $\mathrm{~L} / \mathrm{d}$ & Not used & Not used & Not used & 160 \\
\hline Livestock soil intake $\mathrm{e}^{\mathrm{a}, \mathrm{b}}$ & $\mathrm{kg} / \mathrm{d}$ & Not used & 0.5 & Not used & 0.5 \\
\hline Mass loading for foliar deposition ${ }^{a, b}$ & $\mathrm{~g} / \mathrm{m}^{3}$ & Not used & 0.0001 & 0.0001 & 0.0001 \\
\hline Depth of soil mixing layer ${ }^{b}$ & $\mathrm{~m}$ & 0.15 & 0.15 & 0.15 & 0.15 \\
\hline Depth of roots ${ }^{a, b}$ & m & Not used & 0.9 & 0.9 & 0.9 \\
\hline $\begin{array}{l}\text { Groundwater fractional usage (balance } \\
\text { from surface water) }\end{array}$ & - & & & & \\
\hline Drinking water ${ }^{\mathrm{a}, \mathrm{b}}$ & & 0 & 0 & 1 & 1 \\
\hline Household water ${ }^{\mathrm{a}, \mathrm{b}}$ & & 0 & 0 & 1 & 1 \\
\hline Livestock water ${ }^{3, b}$ & & Not used & 0 & Not used & I \\
\hline Irrigation ${ }^{2, b}$ & & 0 & . 0 & 1 & 1 \\
\hline Storage times of contaminated foodstuffs & d & & & & \\
\hline Fruits, nonleafy vegetables, and grain ${ }^{a, b}$ & & Not used & Not used & 14 & 14 \\
\hline Leafy vegetables ${ }^{2}$ & & Not used & Not used & 14 & 14 \\
\hline Fish $^{a, b}$ & & Not used & 1 & 1 & 1 \\
\hline Crustacea and mollusks ${ }^{a, b}$ & & Not used & 1 & 1 & 1 \\
\hline Milk $^{\mathfrak{a}}$ & & Not used & Not used & Not used & 4 \\
\hline
\end{tabular}


TABLE A.1 (Cont.)

\begin{tabular}{|c|c|c|c|c|c|}
\hline \multirow[b]{2}{*}{ Parameter } & \multirow[b]{2}{*}{ Unit } & \multicolumn{4}{|c|}{ Value } \\
\hline & & Scenario A & Scenario B & Scenario C & Scenario D \\
\hline \multicolumn{6}{|l|}{ Storage times of contaminated foodstuffs (cont.) } \\
\hline Meat and poultry ${ }^{a, b}$ & & Not used & 20 & Not used & 20 \\
\hline Well and surface water ${ }^{b}$ & & 1 & 1 & 1 & 1 \\
\hline Livestock fodder ${ }^{a, b}$ & & Nót used & 45 & Not used & 45 \\
\hline $\begin{array}{l}\text { Total porosity of the house or building } \\
\text { foundation }{ }^{\mathrm{b}}\end{array}$ & - & 0.1 & 0.1 & 0.1 & 0.1 \\
\hline Volumetric water content of the foundation ${ }^{b}$ & - & 0.03 & 0.03 & 0.03 & 0.03 \\
\hline Diffusion coefficient for radon gas & $\mathrm{m}^{2} / \mathrm{s}$ & & & & \\
\hline In foundation material ${ }^{b}$ & & $3.0 \times 10^{-7}$ & $3.0 \times 10^{-7}$ & $3.0 \times 10^{-7}$ & $3.0 \times 10^{-7}$ \\
\hline In contaminated zone concrete ${ }^{a}$ & & $3.0 \times 10^{-7}$ & $3.0 \times 10^{-7}$ & $3.0 \times 10^{-7}$ & $3.0 \times 10^{-7}$ \\
\hline Emanating power of radon-222 $2^{b}$ & - & 0.25 & 0.25 & 0.25 & 0.25 \\
\hline Radon vertical dimension of mixing ${ }^{b}$ & $\mathrm{~m}$ & 2 & 2 & 2 & 2 \\
\hline Average annual wind speed ${ }^{a}$ & $\mathrm{~m} / \mathrm{s}$ & 3.5 & 3.5 & 3.5 & 3.5 \\
\hline Average building air exchange rate ${ }^{b}$ & L/h & 0.5 & 0.5 & 0.5 & 0.5 \\
\hline Height of building (room) ${ }^{b}$ & m & 2.5 & 2.5 & 2.5 & 2.5 \\
\hline Building indoor area factor ${ }^{b}$ & - & 0 & 0 & 0 & 0 \\
\hline Bulk density of house or building foundation ${ }^{b}$ & $\mathrm{~g} / \mathrm{cm}^{3}$ & 2.4 & 2.4 & 2.4 & 2.4 \\
\hline Thickness of house or building foundation ${ }^{b}$ & $\mathrm{~m}$ & 0.15 & 0.15 & 0.15 & 0.15 \\
\hline Building depth below ground surface ${ }^{b}$ & $\mathrm{~m}$ & -1 & -1 & -1 & -1 \\
\hline \multicolumn{6}{|c|}{ a Values based on site specifications, scenario assumptions, or Yu et al. (1993a,b). } \\
\hline \multicolumn{6}{|l|}{ b RESRAD default values. } \\
\hline \multicolumn{6}{|l|}{ c Parameter is dimensionless. } \\
\hline d Calculated with the RESRAD computer code. & & & & & \\
\hline
\end{tabular}

\section{REFERENCES FOR APPENDIX}

Yu, C., et al., 1993a, Manual for Implementing Residual Radioactive Material Guidelines Using RESRAD, Version 5.0, ANL/EAD/LD-2, prepared by Argonne National Laboratory, Environmental Assessment Division, Argonne, Ill., for U.S. Department of Energy, Office of Environmental Restoration, Washington, D.C., Sept.

Yu, C., et al., 1993b, Data Collection Handbook to Support Modeling the Impacts of Radioactive Material in Soil, ANL/EAIS-8, prepared by Argonne National Laboratory, Environmental Assessment Division, Argonne, Ill., for U.S. Department of Energy, Office of Environmental Restoration, Washington, D.C., April. 